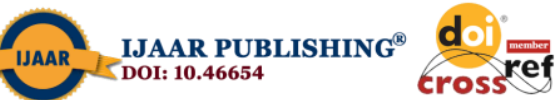

International Journal of Advanced Academic Research (Social and Management Sciences) | ISSN: 2488-9849

\title{
KNOWLEDGE-BASED ENTREPRENEURSHIP: AN AGENT FOR ECONOMIC DEVELOPMENT
}

\author{
Bayo, Princewill Lekara (Ph.D) \\ Department of Management, Faculty of Management Sciences \\ Rivers State University, Port Harcourt, Nigeria \\ bayo.princewill@ust.edu.ng
}

$\boldsymbol{\&}$

Kayii NumbaraBari Emmanuel

Department of Business Education

Rivers State University, Port Harcourt, Nigeria

numbarabari.kayii@ust.edu.ng

\begin{abstract}
National and economic development could be considered to be of paramount interest to citizens of a nation. Persons or people aspiring to take leadership positions should and need to dwell on how to improve the life of the citizens. Several factors stemming from knowledge, education, training and retraining are considered important in economic development. Entrepreneurial skills help in growing the economy; add value and create more jobs for the citizens. They are highly leveraged opportunities for new venture creation and investments. Yet little attention has been paid to them in economic and workforce development or entrepreneurship research and education. Entrepreneurial development is one factor that enhances economic development as it plays vital role in economic growth of a nation. This paper argues that knowledge acquired through education and experience is a vital factor in the entrepreneurial development of a nation, and argues for greater focus of entrepreneurship research, education, and investment in knowledge based services. For entrepreneurial skills to be acquired there is need for quality education and educators. This calls for good educational environment and the desire to learn by the would-be entrepreneurs.
\end{abstract}

Keyword: Entrepreneurs, Entrepreneurship, Knowledge-based, Development. 


\section{Introduction}

A nation can only grow and develop when its citizens acquire basic knowledge of education in getting relevant skills. Entrepreneurial advancement or development is one key-factor that help a nation develop quickly technologically. Every desiring economy that needs development provides the kind of government that will attract investors both local and international into the economy. The importance of entrepreneurship to economic growth and job creation is widely accepted and publicized. Job growth in Nigeria is driven almost entirely by small and medium scale businesses that reach the rapid growth stage. According to Kane (2010), without small and medium businesses, there would be no new job growth in the Nigeria economy. On average, it is evident in most developed countries the government alone cannot employ its teeming unemployed population. Decades ago, entrepreneurs were men and women that could not acquire basic education both at the primary and secondary level, hence taking to such trade acquisition to earn a living, but nowadays, entrepreneurial development is seen world over as one factor that enhanced economic growth of a country. The importance of small and medium business and entrepreneurship to economic growth and job creation has not been lost on government organizations, economic development organizations, business and investment communities, and academic researchers and educators. Today, every business men, manufacturers, investors have the basic knowledge through education, by attending schools, seminars, workshops and being trained in such field. Education and knowledge acquisition open doors for improvement and growth. Many investors are not educated or have vast knowledge in the business, but employ the services of those that have acquired basic education to handle the business. Basic knowledge through education exposes one to entrepreneurial development and the activities of establishing business that will enhance growth. Considering the economic and manpower development drives and strategies employed by the government at all levels, as well as academic research and education in entrepreneurship, much is needed to achieve current and future opportunities through knowledge-based entrepreneurial skill acquisition for economic and manpower development in businesses, industries, and various technological advancement.

\section{REVIEW OF RELATED LITERATURE}

Knowledge-based is the accumulation of facts or information to solve and achieve complex goals. It can also be explained as the use of knowledge acquired into application through computer programme to solve complex problems. Education has several definitions; it is a process that involves social, mental, psychological and emotional development of an individual. According to Omiebi and David (2004), the term or concept is difficult to pin down to a simple definition. Thus, it covers many other variables in knowledge acquisition. According to the work of Hetland (2012), education is not just cognitive and intellectual in nature or learning or acquisition of skills, or competences to do something, it is very broad involving ethical, moral, values, attitude art and more other issues of life. In essence, talking about education and knowledge acquisition, it covers the development of man, the ability and capacity, initiative to do business, associates and face life challenges.

Thus, having known the basic of acquiring the knowledge, entrepreneurial skill therefore is not only knowing how to run business but having the ability to face challenges and handling the risks associated with managing business venture. According to Isaac and Akpan (2004), 
the acquisition of knowledge through business education has the following as it main stage of seeking the basic education necessary of:

(1) Developing the individuals who can meet up modern technological advancement and challenges.

(2) Development of the required manpower with specialized skills capable of the mobilization for natural economic growth.

(3) Prepare and develop the individuals for enhanced attitudes and desired skill towards work life.

\section{The Concept of Entrepreneurship}

The comparative division of manpower development in Knowledge-based entrepreneurship has grown beyond the physical production of manpower that has been decreasing over the last century. This is as a result of those with entrepreneurial skill bringing out ideas and putting those ideas to practical manifestation that the physician workforce uses. Swyt (1988) analyzed the trend and projected composition of the workforce in industries. Swyt's projections have been extended to 2013 using the US Census (Statistical Abstract of the United States, 2014) and the Bureau of Labour Statistics data (Occupation Employment Statistics 2008, 2015). One can see that in 1930, the percentage of the workforce in physical production and occupations accounted for $60 \%$, while knowledge-based workers represented only 7\%. By 1980 those percentages were $34 \%$ and $16 \%$, respectively. Swyt (1988) projected that by 2010 technical professional Knowledge-based workers would outnumber physical production workers, presumably due to increasing automation in manufacturing, production, and services. And that by the end of the 21 st century the skilled workforce would be predominantly management, sales, and administration and knowledge-based entrepreneurial workers. The entrepreneurial concept is the ability to think out a new thing or ways of doing things better. Man is not satisfied with the happening in his/her environment. Thus, the question of how to get some other better ways of solving problems. This problem requires people that have the entrepreneurial skills to turn such efforts into a profitable enterprise. Entrepreneurship is defined differently by different people; some say it is mental ability to innovate, to take risks, or the ability to see and create product that will be profitable. According to Chilakwu (2009), entrepreneurship is the active process of recognizing an economic demand in an economy and supplying the factors of production to satisfy that demand with a view to generate profit, while Chiekezie and Orogbu (2009) opined that entrepreneurship is a mindset that results to the creation and development of economic activities through innovation, risk bearing and quality management of both human and material resources to accomplish set goals. Entrepreneurship has a lot of activities associated with it that has to do with the establishment of business and its operations (Otamiri, Umesi \& Njoku, 2011). Amaehule (2011) stated that entrepreneurship focus on recognizing business opportunities, starting a business based on that opportunity and maintaining the operation of that business to achieve results. Entrepreneurship is the activity of an entrepreneur who put into practice entrepreneurial skills acquired through basic educational training. Entrepreneurs usually try something new. There is hardly anything that exists today that is not as a result of innovation by the entrepreneurs. The use of mobile phones, unmanned aircrafts, and production of images that look like real life on televisions, use of robot to perform tasks meant for human being to do etc., are some of the works of knowledge-based entrepreneurial development.

Some definitions of entrepreneurs are stated below by some scholars: 
(a) Schumpeter (1934) defined an entrepreneur as an innovator who use the process of shattering the status quo of the existing product and services, to set up new products and new services.

(b) David McClelland (1961) defined entrepreneur as a person with a high need for achievement. Such a person is energetic and a risk bearer or taker.

(c) Peter Drucker (1964), an entrepreneur is one that searches for changes, responds to it and exploits the opportunities.

Thus, entrepreneurship could be defined as the aggressive and dynamic process of creating wealth by translating visions, dreams and ideas into viable economical business entities. These are based on the kind of business they do or undertake, e.g. manufacturing, marketing and services. In manufacturing they undertake production of goods, while in marketing they undertake the activities of getting goods reach the consumers as the services includes the provision of other wants of the people that will satisfy their needs. An entrepreneur is one that is ready to take risk, to use his idea and not just a manager. Acquiring entrepreneurial skills can be through mentoring, apprenticeship, understudying a master in a trade or business knowledge and skills.

\section{Uniqueness of knowledge-based entrepreneurship}

The difference between knowledge-based entrepreneurial businesses and physical service or production businesses are considered in the financial and entrepreneurial development characteristics. In the financial characteristics, the entrepreneur considers the money and the sources, risks involved, profits to achieve and the fixed assets and returns on the investment. He does not just jump into the business no matter how lucrative it maybe in the eye. While in entrepreneurial development, he/she considers and analyzes the different data needed as described by Reynolds and Curtin (2008) and Reynolds (2017) to determine the differences in setting up a business exist between Knowledge-based entrepreneurship and physical services or products organizations, such as the designing of a prototype or model of the business, how to obtain supplies or materials and market for the products. And for the workability of this uniqueness to bring out refined entrepreneurs, the following factors are necessary:

(a) Good Environment: For the knowledge and good entrepreneurial skills that will yield results, there must be a conducive environment that will encourage such learning and training. However, this is adversely a different case in Nigeria where social amenities are not available to enhance economic growth. No good road, security system, electricity etc. While tertiary institutions are developing curriculum and courses to enhance entrepreneurial development, the various government and operators of business should support this movement in order to create better knowledge - driven entrepreneurial economy.

(b) Entrepreneurial Mindset: The attitudes and mind of an entrepreneur is different from other individuals in business. These attitudes are having the mindset of starting up a business that will be distinctive from already existing ones. Acquiring only business knowledge is not enough, but having the mental ability to foster the application of such knowledge to yield results and development. The entrepreneurial intention should be channeled toward the 
mindset of changing the situation through innovations, motivation that will help to develop the economy and the citizenry. Believing that every child is an achiever can alter the general mindset of "I cannot do it" to "I can do it better" (Arends, 2007).

(c) Willingness to Learn: The would-be entrepreneurs must have the intention and desire to learn, the learner must be willing, submissive, humble to learn. An unwilling person that cannot learn as an apprentice, or undergo training under a master has the problem of becoming a better entrepreneur. Hence, those interested are enlighten and willing by going through those processes.

(d) Entrepreneurial Development: Entrepreneurial development is the function of quality education, conducive mindset, good environment and the provision of social amenities. This will accelerate development as it is a necessity for entrepreneurial growth to thrive. Government collect taxes from these investors, thus they need to help educate, train and motivate the entrepreneurial skills of the citizenship for economic growth.

\section{DRAWBACKS ON KNOWLEDGE-BASED ENTREPRENEURSHIP}

In spite of the dominance and prospects of knowledge-based entrepreneurship business for new ventures, economic, and manpower development, little attention is being paid to these business and career in economic development programs, university entrepreneurship programs, entrepreneurship research, and public and private investments.

Economic development programs: The search on internet for the activities on economic development shows only a handful of economic development programs worldwide that mention any attention paid to knowledge-based entrepreneurship businesses. Few of such are: Brisbane Economic Development Plan (Brisbane EDP, 2016), Charleston Digital Corridor (Charleston DC, 2014), Cornwall and the Isle of Scilly (Cios, 2011), San Francisco Center for Economic Development (San Francisco CED, 2016), and Singapore Economic Development Board (Singapore EDB, 2016) that have economic development programs which focus on knowledge-based entrepreneurship business.

University entrepreneurship programs: In the past, few university entrepreneurship programs were focused on these types of businesses and professions and entrepreneurship generally, unlike today that most universities have introduced entrepreneurship programme as compulsory for all undergraduates student to offer. These initiatives in entrepreneurship are in the arts, architecture, engineering, health science, and other disciplines. Entrepreneurial education elements are introduced into engineering, science, or arts curricula. The important point is that a more strategic integrative approach is needed to address the unique nature, challenges, and opportunities of knowledge-based entrepreneurship business that focus on knowledge service output, not physical product or service output, irrespective of the business, engineering, science, or arts disciplines required to produce them. 
Academic research in entrepreneurship: The few academic research journals and internet search indicate that few journals address only extensive issues about the sector and its importance and strategies for addressing it. Out of these few only two articles focus on the knowledge-based entrepreneurship. One of such article is (Landström, 2008) which attempts to address the question of why entrepreneurship researchers have not become a stronger voice regarding the understanding of the development of the knowledge-based economy.

Another is (Bahrami and Habib, 2012) that explores entrepreneurship and the knowledge-based economy definitions, prerequisites, consequences, success criteria, and the key role of knowledge and develops a model for knowledge-based entrepreneurship emphasizing the synergy of these two concepts.

Entrepreneurship and Management: There are differences in the difficulties in differentiating between entrepreneurship and management while management is the act of getting things done through other people. The entrepreneur is how to benefit from innovations or inventors by turning them into goods and services that would satisfy human needs.

The entrepreneur may not have the funds or knowledge to achieve the desired goal but he/she may have the mindset which others lack to take risk and the vision into achievable results. Jones and George (2003) as referred in the work of Agbaeze (2007) observed that those who find new business often have difficulty in managing the business as they grow and it is only the entrepreneur that can thrive to achieve in that situation. Management involves all the activities of efficiently and effectively putting together of both human and other resources, minimize the input and then maximize the output to achieving goals set (Agbaeze, 2007). The involvement of management in the effort of the entrepreneur ensures the efficient and effective confirmation of the resources. Entrepreneurs differ from the management of business but that does not mean people having both skills are not available. Therefore, for an entrepreneur to successfully maximize the financial benefits needed, he/she must have a team of management that run the business. This should not be ignored or separated from each other.

\section{ENTREPRENEURIAL DEVELOPMENT ROLE IN AN ECONOMY}

The entrepreneur is a person that his/her activities create or generate employment for the citizens; pay taxes to government for the provision of social amenities, provides commodities to satisfy the people's needs etc. The economy of any nation is based on the goods and services produced locally by her citizens. And this provides employment opportunities and reduces poverty level. The danger of an economy is possible when run based on imported goods, only to service other country economy and development. Nigeria is an economy that relies on imported goods without the citizens patronizing locally made goods. The spirit of developing entrepreneurs and become a creator of jobs is rarely done as a result of this act where government policies are not supporting the provision of grant to would-be entrepreneurs to boost the economy. Looking critically, we import and patronize goods produced overseas than ours, except the blocks we mould, the sand, trees we naturally inherited, if not virtually everything is imported. Nigeria needs men and women with the spirit of an entrepreneur that will generate ideas to develop the economy through his/her skills to produce goods and services needed. Such people will reduce the current trend on the importation of foreign-made goods that carry away our resources. 
The entrepreneurs therefore, play vital roles in the development of any economy through the following:

(a) Through Innovation - The entrepreneur conceives idea and brings them into reality, harnessing the available resources, produce them as output and make them available to consumers.

(b) Harnessing economic resources that would have been abandoned into use, thus creating jobs and funds into the economy.

(c) Consider the risks that may arise in the business and the economy and proffer ways of converting such risks to profitable ventures.

(d) Employment generation or creation to help the government develop the rural and urban areas of the economy, using the resources available to empower the citizens and improve their standard of living.

\section{CONCLUSION}

Training of manpower through basic acquisition of the required knowledge in education to make an entrepreneur is important and necessary to boost the economy. Educational knowledge is the factor that will help the development of the nation.

Entrepreneurs are important to drive entrepreneurial development of an economy not minding the fear of failure but go beyond to create jobs and harness the resources to boost the economy. Knowledge is power and the knowledge gained from education help build the entrepreneurial skills and spirit in the citizens. Entrepreneurship being the main factor that helps to develop the economy drives every economy to be industrialized where the social amenities, manpower needed are in place.

This paper posits that knowledge through basic education acquisition is necessary for entrepreneurial development of the nation. Also that government should use the oil wealth of this nation to provide the social amenities needed to generate entrepreneurial spirit. Therefore, for Nigeria to be industrialized and the needed development achieved, knowledgebased entrepreneurship should be encouraged, training and retaining in the basic skills through education to gain such knowledge on entrepreneurial development of the economy should be included in the nation's higher institutions of learning curriculum.

Earlier and faster development and deployment of business models and marketing and promotion may have the potential for faster advancement and greater probability of success. The fact remains that comparable numbers of businesses achieve profits based on the entrepreneurial visions, ideas and developed proprietary technology that could attract greater investment as a result of greater awareness on the part of investors. This also can contribute to faster and higher value creation and return on investment, as well as manpower and economic development.

Unfortunately, knowledge-base entrepreneurship receives much less attention than non knowledge-base entrepreneurship. Few economic development programs in the world focus on knowledge-base entrepreneurship businesses. Very little academic 
research focuses on entrepreneurship in knowledge-base entrepreneurship businesses.

Few universities academic programmes are focused on the differences in entrepreneurial approach in knowledge-base entrepreneurship and industries. The results will be better if greater attention is given to value creation, return on private and public investment, job creation and enhancement, and economic development of the nation.

\section{RECOMMENDATIONS}

Knowledge-based entrepreneurial businesses and occupation present a significant opportunity for economic and manpower development and public and private investment to create jobs. More additional focus and efforts for academic research, education programmes, economic and manpower development, and investment should be encouraged in the economy.

In view of the discussions in this paper, the following are the recommendations that if applied will help to enhance our entrepreneurial development:

(1) Government should help to develop educational curriculum that pupils in primary school, students in secondary and tertiary levels will learn practical entrepreneurial skills.

(2) Higher education should involve trades that will showcase entrepreneurial skill development. Degrees in entrepreneurial development can also be awarded in Nigerian Universities.

(3) Provision of social amenities by the government to reduce the maintenance costs of running business.

(4) Reduction in multiple taxation and improvement in budgetary allocation for education.

(5) Provision of special funds for research and innovations to higher institutions and research institutes in the country.

(6) Government should define the proposed kind of entrepreneurial education that will enhance growth and development of the economy, business education students real supports and what to use through the knowledge acquired to help the economy grow.

(7) Provision of funds to young entrepreneurs and providing the needed security to be in place for them to thrive. This will go a long way to attract investors and lay proper foundations for the younger generations.

(8) Acceptance of the need for greater focus on, greater interest in, and the resulting commitment of more resources would likely lead to a demand for greater understanding. That demand is likely to lead to a need for more research. Outlining a general framework and suggesting some specific areas for research may be helpful. 
(9) Encouraging entrepreneurial framework process of generating, identifying, and evaluating ideas, and developing the business plan and gathering resources, this will help in growing and managing the business.

(10) Further research into knowledge-based entrepreneurship is possible using entrepreneur characteristics, reasons for starting the business, investment and capital structure, expense structure, employee characteristics, market, customer, and competition. Additional data analysis could provide more detailed information on the difference between knowledge-based entrepreneurship and non knowledgebased entrepreneurship, in particular their evolution, and the reasons. 


\section{REFERENCES}

Agbaeze, E. K. (2007). Development of Entrepreneurship: The Nigerian Perspective, Enugu, Precision Publishers.

Amachule, S. (2011). Entrepreneurial Opportunity for Business Graduates. The Business Journal of faculty of Business Studies, $2(1 \& 2)$, P. 426-431.

Chiekezie, O. M. \& Oregbu, O. L. (2009). Energy Crises and Entrepreneurial Development in Nigeria. In Umubel etc., Management of Small and Medium Scale Business Enterprise in Nigeria. Awka Computer Edge Publishers.

Chilakwu, I. D. O. (2009). Strategies for Entrepreneurial Development and Management of Cooperative Business Organisations.

Hetland, A. (2012). What is Education - always? Accessed on 18/7/2018 at http://www.nation-com.pk/pak'stan-news-newspaper-daily-englishonline/columns/18cet-2012/whatiseducation-always

Isaac, I. J. \& Akpan, O. N. (2004). The Role and Problems of Business Educational Development. International Journal of Educational Development, 7(11).

Jones, G. R. \& George, J. M. (2013). Contemporary Management, New York, McGraw Hill.

Onnoebi-Davids, I. (2004) Skills in Practice of Teaching, Port Harcourt: Minson Publishers.

Oyamiri, S. Omesi, I. \& Njoku, C. C. (2011). Strategies for Entrepreneurship Development in Nigeria. The Business Master, Journal of the Faculty of Business Studies,2(1012)p.24-38.

Bahrami, M \& Habib, M, (2012). Integrated approach to entrepreneurship knowledge based economy: a conceptual model. Procedia-Soc. Behav. Sci. 41, 281-287.

Kane, T., (2010). The importance of startups in job creation and job destruction. Kauffman Found. Res. Ser.; Firm Form. Econ. Growth.

Reynolds, P.D., Curtin, R.T., (2008). Business creation in the United States: panel study of entrepreneurial dynamics II initial assessment. Entrepreneurship 4 (3), 155-307.

Reynolds, P.D., (2017). When is a firm born? Bus. Econ. (52), 81-97.

Swyt, D.A., (1988). The workforce of U.S., manufacturing in the postindustrial era. Technol. Forecast. Soc. Change 34 (3), 231-251.

Tobin, T., Gianiodis, P., (2018). Entrepreneurship unleashed: understanding entrepreneurial education outside of the business school. Journal of Small Bus Management 56 (1), 131-149.

Brisbane Economic Development Plan(Brisbane EDP), (2016). 〈https://www.brisbane.qld.gov.au/about-council/governancestrategy/business-brisbane/ growingbrisbanes- 
economy/brisbanes-economic-development-plan $\rangle$. (Accessed December 2016).

Bureau of Labour Statistics, (2015a). Employment by major occupational group, (BLS Employment Projections), Table 1.1, 〈https://www.bls.gov/emp/ep_table_101. htm〉. (Accessed December 2016).

Bureau of Labor Statistics (2015b). Historical Net Birth/Death, (BLS Net Jobs), 〈https://www.bls.gov/web/empsit/cesbdhst.htm〉. (Accessed December 2016).

Charleston Digital Corridor (Charleston DC), (2014). News, October 16, Charleston's knowledge economy demonstrates continued strength in 2014, 〈http://www. charlestondigitalcorridor.com/. . (Accessed December 2016).

Cornwall \& the Isle of Scilly, (CioS) (2011). The Knowledge economy in Cornwall \& the Isles of Scilly, Peninsula Enterprise. 〈http://www.peninsulaenterprise.co.uk/wpcontent/uploads/2011/10/Kno wledge-Economy.pdf $\rangle$. (Accessed December 2016).

San Francisco Center for Economic Development (San Francisco CED), (2016). Professional Services Sector, 〈http://sfced.org/why-sanfrancisco/sectors/professional-services-2/ $\rangle$.(Accessed December 2016).

Singapore Economic Development Board (Singapore EDB), 2016. Knowledge-Based Economy, 〈https://www.edb.gov.sg/content/edb/en/why-singapore/aboutsingapore/values/knowledge.html $\rangle$. (Accessed December 2016). 